\section{Student Agency in Science Learning: Multimodal and Multilingual Strategies and Practices among Recently Arrived Students in Upper Secondary Schools in Sweden}

\author{
Åsa Wedina, Erica Bomström Aho ${ }^{b}$
}

\begin{tabular}{ll}
\hline Received: & 27 May 2019 \\
Revised: $\quad 09$ July 2019 \\
Accepted: $\quad 02$ September 2019 \\
ISSN: $1307-9298$ \\
Copyright @ IEJEE \\
www.iejee.com
\end{tabular}

DOI: 10.26822/iejee.2019155338

\begin{abstract}
The aim of this article is to develop knowledge about recently arrived students' agency in learning science in upper secondary school in Sweden. The material was created through observations of science lessons and stimulated-recall interviews with four students. Findings showed that the multimodal and multilingual practices students were involved in, and the diverse strategies they used in these lessons, were enabled by their access to multilingual teaching material, including varied digital resources. Students were invited to use varied languages, but this does not, however, mean that the other languages were appreciated, and there is a danger in relying entirely on students' own capacity to translate and understand. Our main conclusion is that students' own agency becomes a prerequisite for learning in these classrooms, but that too much responsibility is put on the students to understand and learn the content and to develop required language skills. With the focus on vocabulary in the teaching, the risqué is high that students do not develop other linguistic skills that they will need in their further studies. Although the agency of these students was visible regarding strategies for their studies, their agency was mainly restricted to learning the prescribed theme in prescribed time.
\end{abstract}

Keywords: Second Language Learning, Agency, Recently Arrived Students, Science Education

\section{Introduction}

Few studies have investigated the use of digital resources in education for recently arrived students (RAS), for whom the language of instruction is a second language. In this article, the focus is on agency among RAS in their science studies, through an analysis of the multimodal and multilingual practices they are involved in and the strategies they use where digital tools play a central part. The increasing use of digital tools such as digital teaching aids, translation tools, and social media have not been followed by enough research on the implication of their use in education and learning. This is particularly the case when it comes to students in multilingual settings and for whom the dominating medium of instruction is a second language that they have recently started to develop. The aim of this article is to develop knowledge about recently arrived students' agency in learning science to qualify for national programs in upper secondary schools in Sweden. Thus, our interest is directed towards student strategies and practices, with a particular focus on the use of varied resources, including digital tools and varied languages.

\section{Students' agency}

In this study of students' agency, a dialogic perspective on agency will be used. This means that agency is defined as dynamic, fluid and as developed in social interaction, allowing for an analysis of individual and social aspects of learning (Ahearn, 2001; Dufva \& Aro, 2015), with the individual understood as being active, complex and unique, situated in cultural and social contexts. Ahearn (2001) defines agency as "the socioculturally mediated capacity to act" (p. 112) and similar to Vitanova et al. (2015), proposes a diverse view of agency. Agency is strongly related to issues of power, which allows for an analysis of those who miss out on the opportunities offered and how these opportunities may be restored. Sociocultural theory directs our focus toward the complex interactions between both individuals and communities and between human cognition and experiences, and following
Holland et al. (1998), a focus on agency allows for an analysis of the interdependent nature of agency (see also Wedin, 2019).

Language Introduction for recently arrived students in Sweden Recently arrived students who arrived to Sweden during adolescence have a particularly challenging situation learning the new language, Swedish, and at the same time using Swedish to learn new knowledge. In Sweden, almost all students who finish compulsory school, grade 9, continue in the non-mandatory upper secondary schools. RAS who have not qualified for a national program before the age of 16 are admitted to Språkintroduktionsprogrammet (Language Introduction Program, here LIP), where they receive education in Swedish as a second language and in school subjects to fulfil the entry requirements. The challenge to develop Swedish to the required level is in itself extremely demanding. Both international (Thomas \& Collier, 1997; Cummins, 2000) and national research (Axelsson, 2013) shows that it takes several years to reach required levels in the new language. Furthermore, most of these students also need to complement previous studies to meet the entry requirements. There is a limit set to the age of 19 before which the requirements should be met. From the age of 19 they will not be admitted to upper secondary school. LIP is thus a transitional program and students are supposed to move on to national programs as quickly as possible. The program has grown quickly over the latest years, and in 2017 was the fifth largest program in Swedish upper secondary school (Swedish National Board of Education (SNAE), 2019).

Education in LIP should be planned individually for each student, following careful mapping procedures. These students have also, according to the Swedish law of education (SFS, 2010:800), the right to what is called Mother Tongue Tuition and Study Guidance through the Mother Tongue (SGMT). Through SGMT, students who need it should get support through a language other than Swedish which they master 
already (Compulsory School Ordinances 2011, 5 chap §4). Under 2015 two percent of the students in compulsory school, about 20 000, received SGMT (SNAE, 2016) and in $201727 \%$ of all students in compulsory school were eligible for Mother Tongue Tuition (SNAE, 2017). Shortcomings have been reported both concerning quantity and quality (The School Inspectorate 2017: 2014), and research has shown discrepancies and problems in the implementation of SGMT (Nilsson \& Axelsson, 2013; Nilsson \& Bunar, 2015; Nilsson Folke, 2015, Reath Warren, 2016, Rosén et al, accepted).

In a situation that is demanding both for schools and students, with a high number of students who need SGMT and with a large number of languages involved, digital solutions that may give students support through their varied linguistic resources are welcome. In this study, all students had access to a laptop with a connection to the Internet, and most of them also used private mobile telephones in class. Through the school, they had access to digital reading services using varied languages, offering students opportunities to listen to textbooks through Inläsningstjänst (ILT, reading services through languages other than Swedish) using applications in their mobile phones, laptops or tablets. In science, they also had access to educational films through SLI, a company distributing films to schools, with subtitles and/or oral talk in Swedish and some other languages that are frequent among RAS. When the observations took place, some of the languages used by students were not available and the translations were incomplete.

\section{Studying science through a second language}

Student agency is important in education but earlier research on science education for students for whom the language of instruction is a second language has mainly focused on teaching and teachers' practices. The importance of relating learning in various subjects to the development of subject-specific language among second language learners has been studied by researchers such as Schleppegrell (2004), Hajer (2006) and Martin (2009). The importance of supporting particularly second language students' development of what may be called a school language have been highlighted by Cummins (2000), among others. The distinction between BICS (Basic Interpersonal Communicative Skills) and CALP (Cognitively Advanced Language Proficiency) was made by Cummins (1984) based on Skutnabb-Kangas and Toukomaa (1976). This distinction between ordinary language and the language used to express knowledge in school, knowledge language or school language, is central for this paper. Later research has emphasised the importance of attending to students' development of both school language and subject-specific language (The Swedish Institute for Educational Research 2018). In different school subjects, language is characterized by specific terms, concepts and thematic patterns (networks of meaning), which makes it even more elusive for a second language learner. The risk is high that students misunderstand the scientific meaning, for example when words have different meaning in everyday language use than in the subject language. One example presented in a Swedish study, Ünsal et al. (2016), is lösning (solution) in chemistry education that was perceived by students to have the meaning of "solution to a problem" rather than "chemical solution". The importance of relating everyday language to science language and to thematic patterns is stressed by Laursen (2006) and Lin and Wu (2015), and also the importance of making students move between different modes of expression.

The importance of supporting L2 students' learning through their earlier developed languages has been stressed by researchers such as Thomas \& Collier (1997),
Cummins (2000), and García (2009). According to teachers in a study from South Africa by Webb \& Treagust (2006), the use of varied languages through code switching and translanguaging, together with an appreciation of students' first languages, was the prime factor behind students' improved skills in scientific reasoning and problem-solving.

Gonzalez-Howard and McNeill (2016) showed that when students were given opportunities to use both the school language, English, and their L1, Spanish, in biology for discussions in small groups, their engagement in science education increased. They observed students who were supported to generate, present and assess science arguments through their L1, Spanish, to develop their knowledge, and then received support to express it in the school language, English. Gonzalez-Howard and McNeill found that the opportunity to use their first language (L1) helped the students to talk about and present the material and content. However, these second language (L2) students still participated to a lesser extent in whole class interaction. Also, Lin and Wu (2015) found that the opportunity to use an L1 helped students to participate in discussions and to develop deeper knowledge. In a study on the use of L1 in the study of wolf ecology, Clark et al. (2012) found that the use of an L1 not only helped students acquire more knowledge, but also to keep their knowledge to a higher extent. Also, Turnbull et al. (2011), who studied education on geology, earthquakes, found that students who were allowed to use both their L1 and L2 in group discussions developed both the L2 and their subject knowledge to a higher extent than those who were restricted to the use of the $L 2$. They showed how the use of students' L1 may widen the content. When a student commented on a stone she was observing: "It looks like it's oxidada.", the teacher got the opportunity to broaden the content to describe the metamorphic process leading to the formation of quartzite, which was not originally included in the lesson plan.

However, Swanson et al. (2014) also problematize the use of an L1 and a reliance entirely on the student to understand translations may obscure understanding, and they exemplify this with a translation by students of tone to Spanish as "el sonido" (sound) instead of "el tono" (pitch). This was also the case in the Swedish study mentioned above (Ünsal et al. 2016), where students' translations to their first languages did not always coincide with the relevant meaning in the lesson. Misinterpretation or mistranslation by students or by other forms of support may lead to a misunderstanding of the given scientific explanation. Manavathu and Zhou (2012) discussed the dilemma of using pictures and simplified language visible, which may facilitate understanding while also being perceived as stigmatizing and infantilising. In their study, one student expressed a dislike of the modified instructional material as follows: “The pictures explain everything ... so when the teacher questions me, she feels like I can't understand anything. The pictures are kinda babyish and I would be so embarrassed" (p. 344). This shows the importance of teachers following individual students' language development, as what is positive for the development of language and knowledge at an early stage may be perceived as simplified and stigmatizing later.

Richardson Bruna et al. $(2007,2010)$ point out the risk of focussing too much on terminology with L2 students, as this tends to deplete the dialogue and restrict the development of science language, while exploratory interactions develop skills for scientific problem-solving and scientific reasoning. Content-rich texts with many nominalizations are characteristic of texts in natural sciences, but they show that a one-sided focus on de-contextualised concepts in teaching may restrict students' development of 
the scientific language. They warn that teachers may then misleadingly think that concepts have to have a central part in teaching. Such an approach may deprive students of a rich linguistic in- and output, and of cognitively demanding thought patterns resulting in artificial and meagre interaction. It may result in students not seeing the connection between concepts and hence not how different systems and phenomena work. To teach science and its language implies teaching students to formulate hypotheses, draw conclusions, evaluate, classify and generalise. Argumentation, which is important in science, consists of two components: on the one hand thesis and evidence, which is the construction of the argument in itself as a thesis supported by evidence, and on the other hand the interaction happening when people present and negotiate arguments. In science subjects, it is also important to get to know and be able to decipher and use explanatory, investigative and instructing texts, and to be able to formulate such texts. In one study, Richardson Bruna et al. (2007) showed that the teacher's focus on terminology in her teaching of the formation of magmatic rocks resulted in overlooking other linguistic components that are used to express relations between concepts and thus restricted the students' opportunities to understand the process itself.

The network of meaning that ties terms and concepts together in what is called semantic relations is not made clear for students when teaching has a one-sided focus on concepts (see also Lemke 1990). Studies by Lin and Wu (2015) and Laursen (2006) showed how teachers' and students' construction of thematic patterns clarified stages in a scientific investigation and gave students opportunities to get acquainted with varied ways to express the same content. Thus, the role of the teacher is highlighted both when it comes to explaining content knowledge and to build relevant language skills used to express this knowledge. By turning the focus towards students' agency, through their strategies and the practices they are involved in, we may develop important knowledge about students' learning.

\section{Conceptual framework, method and research data}

The material for this article was created as part of a research project on RAS in Swedish upper secondary school ${ }^{2}$. Linguistic ethnography was used as the methodological frame for the research (Creese, 2008; Copland \& Creese, 2015; Martin-Jones \& Martin, 2017). Following Copland and Creese, linguistic ethnography links "the micro to the macro, the small to the large, the varied to the routine, the individual to the social, the creative to the constraining, and the historical to the present and to the future" (p. 26). In this case, the use of linguistic ethnography is particularly relevant for analysing a complex phenomenon such as students' agency through their strategies for learning and the practices they are involved in.

Material was created in groups with students who were close to fulfilling the requirements for upper secondary school. A number varying between four and eleven students were present during the observed lessons, which were taught by an experienced science teacher who does not have special training in teaching second language students. The number of students varied between lessons depending on which subjects they needed to fulfil the requirements in for a national program and if lessons were scheduled in parallel. Some students were also often absent as they lived in a stressful situation.

Due to the vulnerable situation for some of the students, ethical issues were carefully considered through the research, and students were carefully informed before consent was gathered.

A variety of material was created during one school year, through observations, interviews and by collecting artefacts, and in this article, field notes and video recordings from observations of eight lessons (each 60-120 min) in biology, physics and chemistry have been used together with teacher and student interviews. An overview of the eight lessons is found in Table 1.

Table 1. Overview of the observed lessons

\begin{tabular}{|c|c|c|c|c|}
\hline & Length & Subject & Topic & Main activity \\
\hline 1 & $60 \mathrm{~min}$ & Chemistry & $\begin{array}{l}\text { Atoms, } \\
\text { ions, elec- } \\
\text { tron shells }\end{array}$ & Copy from blackboard \\
\hline 2 & $60 \mathrm{~min}$ & Physics & Sound & $\begin{array}{l}\text { List with words, find out their } \\
\text { meaning }\end{array}$ \\
\hline 3 & $120 \mathrm{~min}$ & Biology & The skin & $\begin{array}{l}\text { Listen to text book text (simpli- } \\
\text { fied text book), watch film on the } \\
\text { skin (for grades 5-6) }\end{array}$ \\
\hline 4 & $60 \mathrm{~min}$ & Physics & Assessment & Choose one word, explain shortly \\
\hline 5 & $60 \mathrm{~min}$ & Chemistry & Assessment & $\begin{array}{l}\text { Write answers to written ques- } \\
\text { tions, no textbooks or mobile } \\
\text { phones }\end{array}$ \\
\hline 6 & $60 \mathrm{~min}$ & Physics & Light & Lab with rays with a laser pen \\
\hline 7 & $60 \mathrm{~min}$ & Chemistry & Food & $\begin{array}{l}\text { Write a text about "the plate } \\
\text { model" using words such as } \\
\text { proteins and vitamins }\end{array}$ \\
\hline 8 & $60 \mathrm{~min}$ & Physics & Speed & $\begin{array}{l}\text { Listen to texts and read, search } \\
\text { on the Internet }\end{array}$ \\
\hline
\end{tabular}

Four focus students were selected, who were among the high performing students in the group, which may be one reason why they consented to being video-recorded during class and interviewed through stimulated-recall through these recordings. The students, Maryam, Bahar, Hasan and Abdibakar, were video-recorded during two lessons (lessons 7 and 8 in the Table) and then interviewed in pairs. Each interview took about 35 - 45 minutes.

\section{Analysis of the results}

First, practices that students were involved in in classrooms will be analysed based on the observed lessons. Then, students' strategies for learning will be analysed as observed and expressed in the stimulated recall interviews. This means that practices will be analysed from what students were observed to do in class, while strategies will be understood from what students say about what they do to learn. This will finally form the basis for discussing students' agency in the learning process.

\section{Classroom practices}

In this first part, we will focus on what students do, and on what practices related to learning are made visible through observations. The content in this teacher's science lessons, biology, physics and chemistry, was divided in themes, such as in biology "The skin", and followed a similar pattern. Each theme was planned for a certain period and ended with a test. For the tests, students were told that they could hand in texts in a language of their choice and that the teacher had access to help with translation. The final grade would be based on the results of these tests. Of the observed eight lessons, two consisted of tests and the rest of the teacher's presentation of a specific topic followed by students' activities. A lesson would typically start with the teacher presenting a new topic orally with the help of illustrations on the whiteboard and relevant material such as a model of the eye or a film presenting the skin. She only rarely repeated topics from earlier lessons or directed questions to students, such as what they remembered from earlier lessons or if they had understood what she had presented.

For example, during the lesson on ions, Miss M drew a picture on the whiteboard illustrating electron shells and showed how electrons may move between shells to tie atoms together through ions. She wrote the words atom, el- 
ektron, elektronskal and jon (atom, electron, electron shell and ion) on the board, and gave brief explanations of the words. Then, she asked students to copy the drawing from the blackboard of electron shells.

In the physics lesson on light rays, students were given exercises that included experiments. They were placed in pairs, and given laser pens and prisms with and without mirrors, to find out how the light rays were broken. Students were then required to draw the light rays they got on paper. During the four other lessons that were not assessed, students were asked to study in their books, using material of their own choice.

Generally, the lessons focused students' attention on terminology, in the form of more or less isolated concepts. In the lesson on sound, Miss M gave the students a list of concepts, and told them that they would pass if they could explain these during the test. In the lesson on food, she had written some words on the whiteboard, such as, tallriksmodellen (the eat-well plate model, a Swedish model for eating healthily and achieving a balanced diet), kolhydrater (carbohydrates), fetter (fats), proteiner (proteins) and vitamins (vitamins), and handed out some papers where these words were explained briefly. Students were asked to describe a healthy meal following the eat-well plate model by using the given words. The students spent the great part of that lesson looking up explanations of the words through the textbook, the paper, ILT, SLI, and the Internet, writing information about the concepts and then writing the text, which they were required to hand in as the assessment.

As an example of students' practices during this last lesson on food, we will describe the work of Maryam, a girl with Arabic as her first language and one of the high performing students in the group, based on the video-recording and the interview. At the start, Maryam had not understood the task and not the meaning of some of the words, so she asked her class mate, Bahar, for help. Bahar sat at the desk in front of Maryam during this lesson so she turned around with her laptop, and showed the screen to Maryam to show her how she herself had created a table to fill in the words and their explanations. When Maryam asked for the meaning of the word tallriksmodellen, which was the central concept for the lesson and the task, Bahar took the paper that Miss M had handed out, turned the white backside up and drew a picture of a plate with food on and explained the meaning of it. Later, when Maryam asked for the meaning of a word, havre (oat), Bahar took Maryam's laptop, turned it halfway toward herself, found Google translate and the translation of the word in Arabic and then showed the screen to Maryam. Maryam had first understood that they were supposed to write on the paper, but after Bahar's explanation she also constructed a table on her laptop screen and started to fill it in. She took one word at a time, read the explanation on the paper and in the textbook. Then, she looked the word up in Google and some other web pages, such as the ILT pages related to the textbook, and after that, she wrote her explanation in the table on the screen. For some of the words, she used the part of ILT that was related to her textbook as a tool to look up Arabic translations. While she was working, she used her mobile phone and ear phones to listen to music. The text she was required to hand in she did not write during the lesson but according to herself, she did that afterwards at home.

While Maryam and Bahar collaborated to a certain extent, mainly in Arabic, the other nine students present worked individually. Hasan, for example, first used his laptop to look up the words on the internet but after a while realised that he needed the screen to write his explanations that he was to hand in, so he opened his mobile phone and instead used that for his searching on the Internet. The other students worked in similar ways, using the hand-out, the textbook, the laptop and their mobiles, except from one student who had not brought the computer and did not use his mobile, but only the textbook.

Thus, students' practices as observed during these eight lessons were mainly writing explanations for words, listening to the teacher's presentation and assessment. The only occasion when a process was expressed linguistically was during the lesson on ions, when the teacher explained how electrons move between electron shells. Then, students were not asked to express their understanding or to formulate themselves about the process itself. While vocabulary was in focus in the dominant part of the lessons, concepts were generally treated in isolation and it was only in the lessons on ions and food when concepts were related to each other. The process was also in play in the lesson on light rays, when students experimented, but then they were not observed talking about the process while experimenting, but rather focusing on finding the correct results by drawing the expected lines representing the rays.

\section{Students' strategies for learning}

The four focus students, Maryam, Bahar, Hasan and Abdibakar, were asked about their earlier studies and future aspirations, and about their study strategies. They were also shown video clips from the lessons and asked to explain what they had been doing and why. Maryam and Bahar claimed that they had already studied nine years, and Abdibakar that he had studied ten and thus finished the first year of upper secondary school, and thus they claimed that they had studied this earlier so that they did not learn anything new during these science lessons. Hasan, however, said that he had only studied for short periods during his childhood, and thus all that he studied now in science was new to him. In the beginning, this had been very hard, he explained, but he claimed that now when he had already got nine of the required twelve grades, things had become much easier ${ }^{3}$.

Then I didn't know anything that there was the earth round (laughs)

(...)

When you have studied a year much subject then the next year it becomes easier with the others, they are a bit connected. And then now I study I invest a lot in Swedish I read newspaper and books which doesn't apply to or sometimes take from the library and read yes and a little but this year I don't do homework from school I mostly borrow books from the library

Abdibakar, who speaks Somali in his home, had studied in an English medium school in Uganda. Maryam grew up in an Arabic speaking home and her schooling was in Arabic, as was Bahar's education, although she speaks Kurdish and Turkish at home. Thus Abdibakar and Bahar had already had earlier schooling in a second language.

While Abdibakar, Bahar and Maryam perceived that they had a chance to be admitted to a national program before the age of 19, Hasan did not. His aim was to be admitted in adult education, to become an assistant nurse, and later a social educator The other three all aimed for university studies, Abdibakar in computer engineering, Maryam to become a doctor or dentist, and Bahar to become a surgeon, a doctor or an engineer.

All four expressed strategies they use for their learning: to understand the content, to learn Swedish, to remember what they study, and to prepare for the assessments. When they talked about content learning and studying for 
the assessment, they put much focus on learning words and on being able to explain them. Abdibakar said that when he does not understand he searches on the Internet and then asks the teacher the day after.

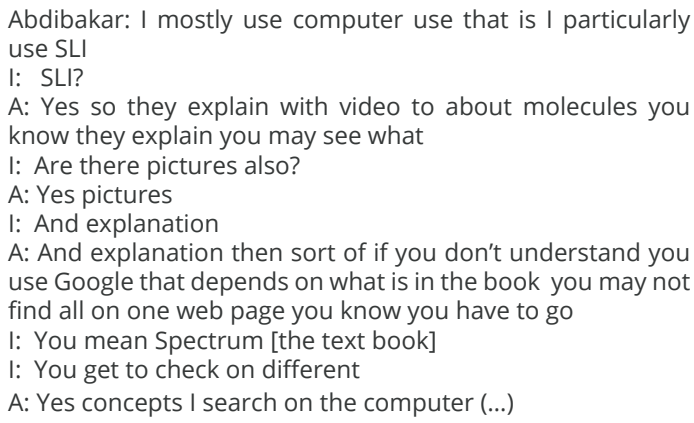

All four said that they use the webpage on ILT for their textbook to find translations of concepts. They all also claimed to study mainly at home. Bahar said that she prefers to watch the films on SLI at home as she learns better there, and Hasan said that he listens when the teacher presents but that he cannot concentrate then. Instead, he uses a strategy of reading the book when he comes home and writing down a summary in Swedish. He stressed that he learns better by reading than by listening. He also said that when there are what he calls "long words", he looks them up in the web page of ILT to get a translation in Dari, while he uses a dictionary for what he calls "common words". He claimed that he never has to study specially for an assessment as he studies all the time, thoroughly from the beginning, and that he studies "not only for the text, for life".

Maryam also talked about how she works with concepts. She starts with words and then draws pictures for her memory, and also writes the word in Swedish, English, Arabic and sometimes even French: "to motivate the concepts, to remember". Also, Bahar stressed her work with words, and that she writes in Swedish and Arabic. She does not write in Kurdish as she claims that she cannot. She usually writes mind-maps to study the concepts as systems, and then creates bulleted lists. She described a strategy that she uses to study a certain topic: first she reads the text in Swedish in the textbook while listening to the ILT-reading in Arabic, and then in Swedish. After that, she writes down "facts" and then makes herself a Powerpoint presentation.

Maryam uses Google to find explanations and searches different web pages until she is satisfied. Then, she writes her explanations down as she remembers them - "as speech" she says. Finally, she reads aloud throughout what she has written to adjust it so that the teacher will be able to understand it. Both Maryam and Bahar claim that they know that they may not rely on Google and say that as they studied these topics before, they may determine if the given explanations are relevant or not.

All four students stress the importance of using both their earlier languages and Swedish. Maryam tells about how she uses her family to learn vocabulary:

Maryam: It helps us a lot to e mix Swedish and the mother tongue between each other

I: In which way does it help you?

$\mathrm{M}$ : For example in the family also my father one time said (.) a word in Arabic and said: But Maryam what is that in Swedish? I just: It is of course? No, he said, it may be eventually. Then I saved it and couldn't forget it. So thus way it helps us.

Thus, she receives help with Swedish words by her father who had been in Sweden for three years and was studying to become an assistant nurse, while when she has learned a Swedish word and does not know its equivalent in Arabic, she asks her mother. She has also developed a strategy to remember a word:

Maryam: If there was a word or a concept then really I sing this word I sing and make sort of my brothers come and dance to that song so then absolutely I will save it I: Does that happen?

$\mathrm{M}$ : Yes that happens very much and e but if there was sort of a lesson or e then I have to sta stay there and motivate it and again read again read again read again then

I: But when you are at home then then you may do more M: yes yes myself

I: Then you sing and your brothers dance I think that sounds wonderful

M: Yes absolutely

I: What words can that be that you dance to, carbohydrate?

M: Oh my good no e (...) yesterday they danced on e it was (...) perhaps it was invite and e support

I: Yes

M: Those two word I could I could not save them and | couldn't (know) the difference between invite (Sw. uppmana) and challenge (Sw. utmana) but my father said again sad again said again and then I singed it and my brothers started to dance to it now I can

Maryam claims to remember new words better if she listens to music when studying, while Bahar draws pictures or makes a mind map, and sometimes records herself saying what she wants to remember and then listens to herself. Sometimes, she also uses a movement or a gesture to help her memory. All four students say that they sometimes send e-mails to their teacher and immediately receive an answer, although Maryam says that she prefers not to ask the teacher all the time.

\section{Findings}

To sum up, these four students have developed varied multimodal and multilingual strategies for learning, using digital tools as well as their varied linguistic resources, including non-verbal language but also gestures, pictures, films, sound and music. These strategies seem to be initiated and developed by the students themselves. During observations, teachers invited students to use them but we never saw any teacher instructing students on how to use the access to varied languages for their development of language and subject knowledge. The teacher's focus on vocabulary is reflected in students' study strategies where both observations and interviews revealed that students put much effort in learning vocabulary. Also assessments focus on vocabulary which means that the support for developing other language skills is weak.

While three of these students claim to already know the content knowledge, those students who need to learn both the scientific knowledge and the language that is used to express it do not get much support for either of these. The relatively rich access to students' other languages through digital tools was mainly used by students to translate between languages. With support these highly motivated students could perhaps have used these to talk science, that is to express the knowledge, processes, relations and procedures orally and in written form, and thus to have combined their subject learning with the development of other aspects of the specialized language of science both in Swedish and their other languages. By navigating between languages students would have had better chance to build both scientific knowledge and language skills necessary for higher studies.

\section{Discussion and conclusion}

School is important for students' learning, but these students claim to do the best part of their studies and to learn better at home. From what we could observe, students were not given much instruction on how to study, and on how to use varied tools. These high-performing students seem to have developed efficient and varied strategies for learning, making use both of their diverse multilingual and multimodal recourses. They were well prepared, three of them through earlier schooling, and the fourth, Hasan, through earlier hard 
studies where he seems not only to have learned important content knowledge, but also to have developed efficient strategies for his studies. This raises the question about conditions for those students who do not have this pre-knowledge, and about the conditions for those students who do not have permanent housing conditions, for example, and thus have to rely on the school building for their studies.

As the school setting is new to the students and the tools available are many, we find that students would benefit from more advice and support, for example on how to use the varied media and their different languages to develop both content knowledge and related language skills, and also, the question of developing subject-specific linguistic skills is an area where more explicit support would help students. For three of these students, this seems to be their main educational need, as they claim to have studied these topics earlier. Allowing students to write tests in any language means that you assess their content knowledge but not their ability to use Swedish to express this. We did not, however, observe any student handing in texts in another language. Thus, their own priority on the Swedish language seems to be stronger than the teacher's.

The focus on vocabulary, and on single concepts, is clear in these lessons and was reflected in students' learning practices and strategies, using a variety of ways to understand and remember concepts. However, we see little of practices where students express processes and relations between concepts, perhaps with Bahar's home-made powerpoints as an exception. The responsibility for understanding concepts and finding the explanations were also to a large extent their own. In the chemistry lesson on food, they were assessed on their use of concepts related to the eat-well plate, but if they were mistaken on concepts, they would have benefitted from support before the assessment. As Richardson Bruna et al. (2007, 2010) showed, the focus on terminology may result in overlooking other linguistic components, such as expressing relations and networks between concepts, thus restricting students' opportunities to understand the processes (see also Lemke, 1990; Laursen, 2006; Lin \& Wu, 2015). This does not necessarily mean that they did not understand these relations, networks and processes, but for their further science studies in Sweden, it will be crucial that they master the Swedish used to express them.

The multimodal and multilingual practices students were involved in, and the diverse strategies they used in these lessons, and outside school, were enabled by their access to multilingual teaching material, including varied multimodal resources. This is positive for their education, as earlier research has shown (such as Thomas \& Collier, 1997; Cummins, 2000; García, 2009; Gonzalez-Howard \& McNeill, 2016; Lin \& Wu, 2015; Clark et al., 2012; Turnbull et al., 2011). However, from what we could see, in this case this also relied mainly on students' own agency. During the observed lessons, the teacher presented the content, and supported students by answering questions, while the responsibility for understanding, as well as for remembering content and developing language skills, lay with the students. Students were invited to use varied languages, but this does not, however, mean that the other languages were appreciated, and as Swanson et al. (2012) and Ünsal et al. (2016) show, there is a danger in relying entirely on the students' own capacity to translate and understand. An example here was Maryam who said that she preferred not to ask the teacher and thus relied on her friend's explanations of the "eat-well plate", the central concept for the task.

Our main conclusion is that students' own agency be- comes a prerequisite for learning during these lessons, and that too much responsibility is put on the students to understand and learn the content and to develop required language skills. With a focus on vocabulary in the teaching, and mainly in the form of isolated words, the risk is high that students do not develop other linguistic skills that they will need in their further studies, such as to use Swedish for arguing, formulating hypotheses, drawing conclusions, evaluating, classifying and generalising.

However, although the agency of these focus students was visible regarding strategies for their studies, there was not much space for students' agency when it came to content, assessment or study pace (time distributed to each topic). Thus, their agency was mainly restricted to learning the prescribed theme in the prescribed time, which may be common in upper secondary schools generally.

Reasons for enrolment in LIP are either that you have not developed the required content knowledge, or that you have not developed the Swedish language skills required to study the content in Swedish, or both. As this study shows, subject teachers should be made aware of recently arrived students' need for support both for developing content knowledge, and the language skills necessary to express it.

\section{References}

Ahearn, L. M. (2001). Language and agency. Annual Review of Anthropology. 30, 109-37.

Clark, D. B., Touchman, S., Martinez-Garza, M., RamirezMarin, F., \& Skjerping Drews, T. (2012). Bilingual language supports in online science inquiry environments. Computers \& Education, 58(4), 1207-1224.

Compulsory School Ordinance (2011). Svensk författningssamling. [Swedish Code of Statues] 2011:185.

Copland, F. \& Creese, A. (2015). Linguistic Ethnography Collecting: Analysing and Presenting Data. Los Angeles: SAGE.

Creese, A. (2008). Linguistic Ethnography. In K. King \& N. Hornberger (Eds. 2nd ed.) Encyclopedia of Language and Education, 229-241. New York: Springer.

Cummins, J. (1984). Bilingualism and Special Education: Issues in Assessment and Pedagogy. Clevedon, UK: Multilingual Matters.

Cummins, J. (2000). Language, Power and Pedagogy: Bilingual Children in the Crossfire. Clevedon: Multilingual Matters Lt.

Dufva, H. \& Aro, M. (2015). Dialogical view on language learners' agency: Connecting intrapersonal with interpersonal. In P. Deters, Ping, X. Gao, E. R. Miller \& G. Vitanova. (Eds.) Theorizing and Analyzing Agency in Second Language Learning: Interdisciplinary Approaches. 37-53. Bristol: Multilingual Matters.

García, O. (2009). Bilingual Education in the 21st Century: A Global Perspective. Oxford: Wiley-Blackwell.

González-Howard, M., \& McNeill, K. L. (2016). Learning in a community of practice: Factors impacting English-learning students' engagement in scientific argumentation. Journal of Research in Science Teaching, 53(4), 527-553. 
Hajer, M. (2006). Inspiring teachers to work with content-based language instruction: Stages in professional development. In I. Lindberg \& K. Sandwall (Eds.) Språket och kunskapen: Att lära på sitt andraspråk i skola och högskola. [Language and Knowledge: Learning in your Second Language in School and Higher Education] 27-46. Gothenburg: Institutet för Svenska som Andraspråk, Rosa-serien.

Holland, D., Skinner, D., Lachicotte, W. Jr \& Cain, C. (1998). Identity and Agency in Cultural Worlds. Cambridge: Harvard University Press.

Laursen, H. P. (2006). Andetsprogsperspektiver på tematiske mønstre i naturfagsundervisningen. [Second language perspectives on thematic patterns in science education] Nordand, 1(1), 51-72.

Lemke, J. L. (1990). Talking Science: Language, Learning, and Values: Ablex Publishing Corporation.

Lin, A. M. Y., \& Wu, Y. (2015). 'May I speak Cantonese?': Co-constructing a scientific proof in an EFL junior secondary science classroom. International Journal of Bilingual Education and Bilingualism, 18(3), 289-305.

Manavathu, M., \& Zhou, G. (2012). The impact of differentiated instructional materials on English language learner (ELL) students' comprehension of science laboratory tasks. Canadian Journal of Science, Mathematics \& Technology Education, 12(4), 334-349.

Martin, J. R. (2009). Genre and language learning: A social semiotic perspective. Linguistics and Education, 20, $10-21$.

Martin-Jones, M. \& Martin, D. (2017). Researching Multilingualism: Critical and Ethnographic Perspectives. London: Routledge.

Nilsson, J. \& Axelsson, M. (2013). "Welcome to Sweden": Newly arrived students' experiences of pedagogical and social provision in introductory and regular classes. International Electronic Journal of Elementary Education, 6(1), 137-164.

Nilsson, J. \& Bunar, N. (2015). Educational responses to newly arrived students in Sweden. Understanding the structure and influence of post-migration ecology. Scandinavian Journal of Educational Research, 60(4), 399-416

Nilsson Folke, J. (2015). 'Sitting on embers': A phenomenological exploration of the embodied experiences of inclusion of newly arrived students in Sweden. Gender and Education, 28(7), 823-838.

Reath Warren, A. (2016). Multilingual study guidance in the Swedish compulsory school and the development of multilingual literacies. Nordand, 11(2), 115-142.

Richardson Bruna, K., Vann, R., \& Perales Escudero, M. (2007). What's language got to do with it?: A case study of academic language instruction in a high school "English Learner Science" class. Journal of English for Academic Purposes, 6(1), 36-54.

Richardson Bruna, K., Vann, R., \& Perales Escudero, M. (2010). "You got the word now": Problematizing vocabulary-based academic language instruction for English Learners in science. The Tapestry Journal, 2(1), 19-36.

Rosén, J., Straszer, B. \& Wedin, Å. (accepted). Studiehandledning på modersmål: Studiehandledares positionering och yrkesroll. [Study guidance in the mother tongue: The positioning and professional role of study guid- ance assistants]

Schleppegrell, M.J. (2004). The Language of Schooling: A Functional Linguistics Perspective. New Jersey \& London: Lawrence Erlbaum Associates, Publishers.

SFS (2010:800). Språklag [Language Act] https://www.riksdagen.se/sv/dokument-lagar/dokument/svensk-forfattningssamling/skollag-2010800_sfs-2010-800

Skutnabb-Kangas, T. \& Toukomaa, P. (1976). Teaching Migrant Children's Mother Tongue and Learning the Language of the Host Country in the Context of the Cocio-cultural Situation of the Family. Helsingfors: Finlands undesco-kommission.

Swanson, L. H., Bianchini, J. A., \& Lee, J. S. (2014). Engaging in argument and communicating information: A case study of English language learners and their science teacher in an urban high school. Journal of Research in Science Teaching, 51(1), 31-64.

Swedish National Agency for Education (2016). Skolverkets allmänna råd med kommentarer: Utbildning för nyanlända elever. [General Advices with Comments: Education for Recently Arrived Students.] Stockholm: Skolverket.

Swedish National Board of Education (2017). Skolverkets statistikdatabas. [Statistics of Swedish National Agency for Education]. Swedish National Agency for Education. Accessed 2017-12-31. https://www.skolverket.se/statistik-och-utvardering/statistik-i-tabeller/ grundskola/skolor-och-elever

Swedish National Board of Education (2019). Skolverkets statistikdatabas. [Statistics of Swedish National Agency for Education]. Accessed 2019-07-10. https://www.skolverket.se/skolutveckling/statistik/ arkiverade-statistiknyheter/statistik/2019-03-07statistik-over-gymnasieskolans-elever-2018-19

The School Inspectorate (2014). Rapport 2014:03. Accessed 2015-12-31. https://skolinspektionen.se/Documents/ Kvalitetsgranskning/nyanlanda-2013/nyanlanda-rapport-03.pdf.

The School Inspectorate (2017). Skolhuvudmäns mottagande av nyanlända elever i grundskolan. [Reception among school authorities of recently arrived students in primary school ] Accessed 2019-07-10. https://www. skolinspektionen.se/sv/Beslut-och-rapporter/Publikationer/Granskningsrapport/Kvalitetsgranskning/ skolhuvudmans-mottagande-av-nyanlanda-elever/ Some

The Swedish Institute for Educational Research (2018). Språkoch kunskapsutvecklande undervisning i det flerspråkiga klassrummet - med fokus på naturvetenskap. [Language and knowledge developing education in the multilingual classroom: With focus on science] Skolforskningsinstitutets systematiska översikter.

Thomas, W.P. \& V.P. Collier (1997). School Effectiveness for Language Minority Students. Washington: National Clearinghouse for Bilingual Education. http://www. ncbe.gwu.edu/ncbepubs/resource/effectiveness.

Turnbull, M., Cormier, M., \& Bourque, J. (2011). The first language in science class: A quasi-experimental study in late French immersion. The Modern Language Journal, 95, 182-198.

Webb, P., \& Treagust, D. F. D. (2006). Using exploratory talk 
to enhance problem solving and reasoning skills in grade-7 science classrooms. Research in Science Education, 36(4), 381-401.

Wedin, A. (2019). Literacy and agency: The case of young adults who came to Sweden as unaccompanied asylum-seeking children. Scandinavian Journal of Educational Research. https://www.tandfonline. com/doi/full/10.1080/00313831.2019.1595710

Vitanova, G., Miller, E. R., Gao, X. (Andy), \& Deters, P. (2015). Introduction. In Deters, P., Gao, X., Miller, E. R. \& Vitanova G. (Eds.) Theorizing and Analyzing Agency in Second Language Learning: Interdisciplinary Approaches, 1-16. Bristol: Multilingual Matters.

Ünsal, Z., Jakobson, B., Molander, B.-O., \& Wickman, P.-O. (2016). Science education in a bilingual class: Problematizing a translational practice. Cultural Studies of Science Education, 1-24. 